\title{
Developing ethnic identity questions for Understanding Society
}

\author{
Alita Nandi \\ University of Essex \\ anandi@essex.ac.uk \\ Lucinda Platt \\ Institute of Education, London
}

(Received May 2011 Revised December 2011)

\begin{abstract}
Ethnic identity, its formation, expression and consequences are sources of extensive discussion and debate within multicultural societies. Analysis of identity is increasingly finding its way into survey-based analysis and is being explored by disciplines beyond psychology, and qualitative and theoretical sociology. However, effective and appropriate survey measures of ethnic identity that are suitable for inclusion in a general purpose sample survey and which allow estimation of change and development across the age range are in short supply. Here, we describe the process of development of a series of new ethnic identity questions, designed specifically for inclusion in Understanding Society but with applicability for longitudinal studies further afield. We detail the rationale for the development and the process by which the final set of questions was arrived at, and outline the implications for future research agendas.
\end{abstract}

Keywords identity; measurement; ethnicity; UKHLS; survey;

\section{Introduction}

Ethnic identity is a source of extensive discussion and debate within multicultural societies. Movements of people as a result of forced and economic migration bring into relief ethnic identity through consciousness of difference and awareness of others' reactions and ascriptions (Jenkins 1994). Ethnic conflicts and genocides highlight the extreme consequences that can ensue from the construction of ethnic boundaries and from investment in identification with one's own 'group' while denying the value - or even humanity - of outgroupers (Banton 2000; Brubaker and Laitin 1998; Olzak 2006). At an individual level, identification with a dominant or marginalised group has been shown to have consequences for self-esteem and can affect achievement and well-being in very tangible ways. Issues of group belonging and identification are thus highly significant for individuals and can have consequences for societies; but they also become more or less salient according to location and context.

Within Western European countries, the maintenance of minority ethnic identities can be experienced or perceived as both threatening and adaptive. Claims associating strong ethnic identification with both positive and negative individual and social outcomes abound and are contested. Increasingly, researchers seek ways to explore and address such claims. For example, there are ongoing debates about social and spatial ties among minority ethnic groups and whether these lead (negatively) to self-segregation or (positively) to cohesion. See, for example, Georgiadis and Manning 2011; Battu and Zenou 2010; Finney and Simpson, 2009, for various takes on such debates. Yet clear interrogation of the nature and strength of specific ethnic identifications, and their consequences, is 
hampered within quantitative social science by lack of direct measures of ethnic identity - alongside lack of consensus as to the forms in which identity is itself constituted.

There are a range of psychological measures of identity or orientation towards ethnic group (Phinney 1992), and there is also a wealth of qualitative research material exploring how particular ethnic groups express or understand their ethnic identity. But despite the need for appropriate measures (Aspinall 2000), and increasing interest among researchers (Manning and Roy 2010; Constant and Zimmerman 2008), there are no comprehensive suites of questions on ethnic identity in social survey research, outside a small number of specialist surveys. Even within specialist studies of migration, questions on ethnic identification are often scarce or unidimensional (Güveli and Platt 2011). Researchers therefore typically have to make do with proxies of ethnic identity or with simple categories.

The aim of the research outlined in this paper was, therefore, to explore and develop survey measures for application in general purpose surveys. It worked with a concept of ethnic identity that was explicitly multifaceted and multidimensional. It also employed an approach that was intended to meet the varying needs of researchers with different questions to answer and with different preconceptions about what ethnicity and identity mean. Thus, while drawing on insights from psychology, economics and sociology, the measures were not intended to represent a single uniform concept of ethnicity, but instead to work flexibly with existing and emerging research concerns that located ethnic identity or proxied it in: patterns of association, religious affiliation, cultural practices, individual expression, national origins and transnational interchanges, and in all or some of these dimensions of self-hood and identification.

Ethnic identity is formed or shaped relationally, through interaction with others (Barth 1969). Other actors contribute to maintenance or subversion of ethnic identity through acceptance or rejection of expressed identity, and through processes of ascription. This can include, though is not limited to, discrimination and ethnic hostility. To understand the development of identity it is therefore also critical to have some understanding of social context and others' perceptions. Nevertheless, it is a complex question how these can adequately be measured in tandem with expressed identities (Heath and Cheung 2006).

We were concerned to locate ethnic identity in relation to individuals' social identities more broadly and to recognise that ethnic identity was just one element of people's sense of self - and not necessarily, or always, the most important. Ethnic identity intersects with other aspects of social identity, both ascribed, such as gender, and chosen such as sports or music preferences. Depending on context, these may be felt as more salient to an individual than their ethnic identity, or shift in relative strength. Nevertheless, while locating ethnic identity within a broader concept of social identity, the main aim of the process described here was to measure ethnic identitity(ies) specifically.

Tajfel (1981) described social identity as "that part of an individual's self-concept which derives from his knowledge of his membership of a social group (or groups) together with the value and emotional significance attached to that membership". Tajfel highlighted the important distinction that has been extended in more recent research between what Turner et al (1994) describe as "self-categories" that define the individual as a unique person in terms of his or her individual differences from other (in-group) persons, and social identity that represents "social categorisations of the self and others".

An alternative formulation of the private/public self distinction was put forward by Abrams (1996) who distinguished a private self that "contains knowledge of one's own attitudes, traits, feelings and behaviour" and a social self consisting of group memberships or categories. Abrams introduced the notion of process to the private-social dichotomy, whereby people can shift between feeling that their characteristics are part of their private self to asserting them as a social category, depending on the context. A category such as national origin can be internalised as a private characteristic, or a characteristic such as professional status can be externalised as a social grouping.

Phinney (1990) found that while researchers into ethnic identity by and large agreed with Tajfel's definition, they tended to focus on different "components" of identity, such as personal affiliation, practices, patterns of association, feelings of belonging to one's own ethnic group, 
and so on. ${ }^{1}$ These components may be temporarily specific and shift with context in different ways.

Ethnic identity is formed and develops. This is regarded as occurring primarily during adolescence as part of the general process of identity formation (Erikson 1963). But affiliation to a group and strength of identification with that group may change throughout life. Specifically, it could change in response to both events in an individual's life (such as migration or marriage, or experience of discrimination) and to external events, such as war and other political events (Ahmad and Evergeti 2010; Birt 2009), changes in law and the public sphere, and neighbourhood and wider demographic change.

Changes in strength of identification both as part of identity development and in response to changes in context may take the form of accentuation of one or more of the components of ethnicity. Moving to a new country, for example, a person may slowly change her food and dressing habits to reflect the practices of that country, but she may still retain a strong sense of belonging to her country of origin and interact frequently with others from that country (see also Schaafsma et al 2010). By contrast, another immigrant may choose to express her national identity by her dress and food, even if she does not interact frequently with others from her homeland. There is no reason to believe $a$ priori that changes in people's identification with their ethnic group operate through similar patterns of change across components of identity.

For these reasons, as well as allowing flexible survey measures that would meet different conceptions of ethnicity and address varying questions on ethnic ties, boundaries, self-concept, and emotional significance, we sought to develop a series of measures that would be susceptible to changes in experience and context and would allow researchers to investigate such change.

\section{Approaching ethnic identity measurement}

In seeking models of identity measurement, we explored, but also moved beyond, existing survey measures that attempt to enumerate mutually exclusive ethnic group categories mostly for demographic (counting) purposes. These measures aim to capture some degree of stability in identification and group belonging. While necessary for the construction, implementation and evaluation of public policies, they fall short of being good measures of ethnic identity particularly because they ignore the dynamic, fluid and multidimensional nature of ethnic identity (Burton, Nandi and Platt 2010) and can treat different aspects of identity as if mutually exclusive. There is also a paucity of measures which can capture the range of components through which ethnic identity is expressed.

It was hoped that the new measures would meet a swiftly expanding research agenda into the formation, expression and consequences of ethnic identity and, in the process, go some way towards engaging a wider range of ethnicity researchers with survey research. No single ethnic group question is likely to be sufficient to match the interpretation and theorisation of ethnicity of different disciplines and researchers. Allowing researchers maximum flexibility in how they can construct groups and giving them a large range of potential dimensions of ethnicity (e.g. language and religion) and across components (e.g. self-concept and belonging) was felt to be optimal in constructing identity questions.

For developing such an ambitious suite of ethnic identity questions, the application to a multipurpose longitudinal household study such as Understanding Society offered both constraints and opportunities. In terms of constraints:

- it was critical that any questions should be comprehensible to participants in a natural setting with little explanation

- they should be acceptable to participants (Aspinall 2002)

- $\quad$ they should be relatively mode invariant to allow for future replication regardless of any changes of interview mode within the survey

- they should absorb a relatively short amount of time.

In terms of opportunities, the survey offered the potential:

- for repeating these questions over time and therefore capturing development of identity especially among groups thought to 
be most sensitive to change and development (young adults and migrants)

- to draw on existing answers to questions on specific dimensions of ethnic identity such as religious affiliation or categorical measures of ethnic group that had been collected in earlier sweeps of the survey

- for complementing ethnic identity questions with those that were collected on other aspects of identity and behaviour, such as on gender identity, occupation, gender role attitudes etc. ${ }^{2}$

- to look at identity across a wide age range, across different ethnic groups, first and second generation migrants

- to use the questions on ethnic identity to understand how strength and nature of ethnic identity of different members of a family compare.

We approached the task of question development through a series of questions which we aimed to answer using different methods that were appropriate to each question. We also drew as far as possible on existing insights (Burton, Nandi and Platt 2010) and research and survey practice to inform an appropriate development strategy.

The questions that guided our research were:

1. Can identity questions generally command an acceptable level of response (i.e. close to $100 \%)$ and incorporate sufficient variance to render them suitable for analysis?

2. Can we ask ethnic identity questions such that they are likely to be mode invariant?

These two questions we addressed by fielding a suite of simple strength of identity questions (including but not restricted to ethnic identity) in the Innovation Panel of Understanding Society (see section 3).

3. Can people agree on what constitutes an ethnic group or their ethnic identity?

To address this question we ran a series of focus groups in order to understand how people debated their understandings of ethnicity and the extent to which they could develop a common position (see section 4).

4. How best is it possible to ask questions that accommodate people's desire to assert multiple identities?

5. How would it be best to ask questions to measure different components of ethnicity?

These questions were addressed through a series of semi structured interviews (see section 5 ).

6. Can questions be made comprehensible and work in a survey style setting?

To address whether the measures we had developed over the preceding stages could actually deliver and be comprehensible to participants, we cognitively tested them with different respondents, mimicking the survey setting and then addressing suitability and comprehensibility (see section 6).

\section{Testing general identity questions in the Innovation Panel}

We initially looked for existing identity measures that could be modified to measure ethnic identity, and that we could test for their robustness within the Understanding Society survey context. In addition to finding ideal measures of ethnic identity, we wanted to place these within the context of a comprehensive identity module that would include other dimensions of identity, such as gender, age and life stage, occupation. The Innovation Panel, a panel of 1500 British households interviewed in the year prior to the main Understanding Society survey to test methodological issues, provided the ideal opportunity for such testing (see Buck and McFall, this issue).

Our review of existing questions led us to a module of questions on identity (across different domains) fielded in the Citizenship Survey ${ }^{3}$ (via faceto-face interviews). The question asked respondents to say how important each of the domains was to their sense of who they were on a four point scale (see Appendix). As these questions had been carried in the Citizenship Survey for a number of years and had been subject to prior testing we could assume that they worked reasonably well. But some domains were difficult to interpret and few key domains were missing. Also, 
we did not know whether responses would differ by interview mode.

So, we decided to ask these questions across a modified set of domains (see Appendix) in the second wave of the Innovation Panel sample, which had the added advantage of being conducted faceto-face and by telephone. We reduced the number of response options from four to three, since mode differences are less for fewer response options (De Leeuw 2005).

We found that these questions worked well and with very modest mode effects (Nandi and Platt 2011). Overall, the results suggested that the questions were by and large suitable for inclusion in Understanding Society; but feedback from interviewers was that the module length was burdensome for respondents. The recommendation for the general identity module was to ask a smaller number of items and in a self-completion format, which would reduce further any effects associated with mode of delivery.

\section{Focus group research}

We aimed to establish the extent to which people could express common understandings of ethnicity and ethnic identity and to draw out what was salient to different individuals. We wanted to establish the extent to which a public consensus could be reached as well as being able to highlight which dimensions of ethnic identity individuals spontaneously drew attention to. Focus groups allowed us to identify what is socially acceptable, which can differ from what people will disclose in a one-to-one situation. In line with practice for ensuring the effective working of the focus groups and the possibilities of reaching consensus within each group, we aimed for relative homogeneity, while seeking diversity across the groups (Bloor et al 2001). Homogeneity was constructed in terms of education, age, and whether minority or majority ethnicity and diversity by conducting focus groups in different regions (London, Colchester and Sheffield). Within the minority group focus groups, we allowed diversity in terms of categorical ethnic group origins, to help foster debate and discussion (see Table 1).

Table 1. Sample characteristics of the focus groups

\begin{tabular}{|c|c|c|c|}
\hline Location & Age and gender & Socio-economic class & Ethnic categories \\
\hline London & $\begin{array}{l}\text { Young men and } \\
\text { women }\end{array}$ & $\begin{array}{l}\text { Middle to lower social } \\
\text { class }\end{array}$ & $\begin{array}{l}\text { Different non-white } \\
\text { minority ethnic groups }\end{array}$ \\
\hline London & $\begin{array}{l}\text { Young men and } \\
\text { women }\end{array}$ & $\begin{array}{l}\text { Middle to higher social } \\
\text { class }\end{array}$ & $\begin{array}{l}\text { Minority ethnic white and } \\
\text { non-white ethnic groups }\end{array}$ \\
\hline London & Older men & Middle to lower & $\begin{array}{l}\text { Different non-white } \\
\text { ethnic groups }\end{array}$ \\
\hline Colchester & $\begin{array}{l}\text { Young men and } \\
\text { women }\end{array}$ & $\begin{array}{l}\text { Mixed educational } \\
\text { levels }\end{array}$ & White British \\
\hline Colchester & $\begin{array}{l}\text { Older men and } \\
\text { women }\end{array}$ & $\begin{array}{l}\text { Middle to lower social } \\
\text { class }\end{array}$ & White British \\
\hline Sheffield & $\begin{array}{l}\text { Older and middle } \\
\text { aged women }\end{array}$ & $\begin{array}{l}\text { Middle to lower social } \\
\text { class }\end{array}$ & Pakistani \\
\hline Sheffield & $\begin{array}{l}\text { Older and middle } \\
\text { aged women }\end{array}$ & $\begin{array}{l}\text { Middle to lower social } \\
\text { class }\end{array}$ & $\begin{array}{l}\text { Black African and Black } \\
\text { Caribbean }\end{array}$ \\
\hline
\end{tabular}


There were four main discussion points in these focus groups. ${ }^{4}$ The first related to the domains of identity ("key things about ourselves"). The groups discussed: why the aspects mentioned were important to them. They also debated how important these different aspects were in relation to one another. The second discussion point revolved around the meaning of 'ethnicity / ethnic identity' and its dimensions. The third element involved discussing participants' own ethnic identity. They talked about the importance of ethnicity to their sense of self; what they thought ethnicity said about them; and whether the importance of ethnicity varied in different contexts and with others' expectations and with their life course stage. They also considered whether their perception of their identity had changed in recent years, and if so how and why. The final discussion point took the existing 2001 Census classification as its starting point. Participants reflected on it in light of the preceding discussion.

Each focus group was recorded (with participants' permission) and transcribed in full. The authors read the transcripts, reinforced by listening to the tapes, and highlighted themes and observations. These were then discussed and reviewed in an iterative process to enhance validity and robustness of interpretation (Morse et al 2002; Fossey et al 2002).

The first key point to emerge was that there was no agreement either within or across participants about what constitutes an ethnic group. For some it was roots: for example, one participant spoke about "where I come from". For others, it was captured in terms of language, religion, nationality, skin colour, shared values and attitudes. Some understood ethnicity as combining these different aspects. Participants in one group considered the different positions put forward, with one then asserting "You can break down ethnicity into attributes likes colour, race and language". No consensus emerged as to the core features of ethnic group, though there were recurrent elements that were acknowledged by the whole group.

Participants provided extensive information on how and why different dimensions of ethnicity (roots, religion, skin colour) were important to them. For example, in one discussion a participant cogently summarised the centrality of skin colour to his specific British identity: "So the Black comes with the British for me." Aided by the focus group format, participants discussed what information they wanted to convey to others, such as pride in "being who you are", and their sense of cultural difference. They linked these communicative aspects of ethnicity back to the various different dimensions that they had discussed. A key point of discussion (sometimes heated) in several of the groups was the feeling that certain values and beliefs were absolutely integral to their ethnic identities and this was, critically, what they expected to transmitted to their children. One participant expressed this conception of ethnicity in the following terms: "In ethnicity, it brings me back to the values. Ethnicity propels you proper on how you must live, and work is included. It's not separate." However, the strength of conviction expressed here was not common to all the respondents, even though the relevance of values was a common theme across the groups.

Some aspects, that we had not anticipated, came up spontaneously, such as how participants' identities were expressed through particular foods. This came up in almost every group and not just in relation to religious proscriptions. One participant summed up this prevailing relation of food to ethnicity when she said: "I've always cooked Jamaican food and give my grandchildren Jamaican food - I'm a Jamaican." Furthermore, one group discussed how ethnic identity could travel back to the land of their ancestors "...but I think that I'm an African, whether unfortunately I was taken, or my forefathers were taken to the West Indies or America or left Africa or taken to Haiti or Jamaica, that's not going to change who I am".

For minorities, there was substantial evidence of the centrality of ethnic identity, even if aspects of it were felt to be adaptable. They were largely at ease in discussing their ethnicity and what it meant for them, because it was ever-present in their lives. One said: 'Ethnicity for me is as important as my name because it is my identity. It's a part- on a larger scale it is my identity.' While another: 'It always matters where you come from what origin you are; and tradition and culture it changes with time.' By contrast, for majority (and to a certain extent for white minority) respondents, ethnicity was a property of 'others' (typically 'immigrants'). Being the majority and the perceived 'norm', respondents struggled to find ways of expressing their identity or even to talk about its lack of 
salience. One group attempted to move away from self-scrutiny and to talk about the 'proper' subjects of any discussion on ethnicity (i.e. minorities); although in the other majority group, there was a greater attempt to engage with the fact that ethnicity was little considered and largely not meaningful in their personal constructions. This comes through in the following quotation: 'I don't think much about my ethnic group.... It's the obvious thing for me, I'm white, I cannot change it and probably it influenced who I am at the moment, shaped me somehow, but I just don't know.'

There was also substantial discussion of other central aspects of identity across the groups. Those characteristics emphasised varied across the groups, but included gender, politics, family status, interests, work and a very strong emphasis in certain groups on educational level as fundamental to both identity and interpersonal relations. Groups also discussed how they could 'use' things about themselves to find points of connection with others; and how ethnicity, or components of ethnicity, related to other parts of their identity. We were also struck by the strength of regional identities across our respondents: "I wouldn't see it in terms of nationality, wouldn't be like I'm British or Irish, I wouldn't be proud of that. It wouldn't kind of occur to me. I'd much rather describe myself, for example, as a Londoner."

In taking forward our findings by this point and in formulating the next stage of the research, we came to the following conclusions. First, we concluded that while ethnic identity is largely salient for minorities, ethnicity or ethnic group is not a concept that we should be directly asking respondents about in those terms. Second, we noted that the different dimensions of ethnicity that were emerging as significant for respondents were country of origin, skin colour, language, nationality, regional identity, roots (family origins), ancestry. Third, the components of ethnic identity that people (largely) agreed upon were belonging, shared values, pride, ethnicity as communication, private sense of defining principles, association, differentiation, communal activities including cooking and eating, and familiarity. These cross the private/public dichotomy presented by Abrams and discussed in the introduction. Finally, the participants, debating the issue in a communal context were clear that the views of others mattered and that their identity expression was not, and could not be, independent of that external gaze.

\section{Semi-structured interviews}

We wanted to move on from the insights achieved in these relatively free discussions to explore whether some of the expressions of identity would work in a one-to-one interview context. That is, to examine if particular forms of questions were meaningful, would be acceptable and would also produce sufficient variation in responses across a selection of respondents. While the Citizenship Survey offered us one model form for asking questions of ethnic identity, we wished to extend the coverage in depth and range, i.e., across different dimensions and components. It is worth noting that these interviews were just one particular stage in our question design process, and allowed us to engage with respondents whom we felt might engage with our provisional questions in particular ways, including by challenging them (as a number did). We used these semi-structured interviews (with cognitive probes) to access more highly educated, professional respondents, because they had not featured greatly in our focus groups (such respondents are typically much harder to recruit to focus groups). We also thought they might have relatively greater investment in their professional identities as core to their self-concept, leading them to give a rather different perspective from the focus groups.

We prepared an interview schedule containing both semi-structured questions and prompts, alongside sample questions with specific probes to test specific question wording (Collins 2003; Presser et al 2004). The schedule went through ten versions before it was piloted. Further iterations and modifications took place as the researchers reflected on each interview.

In total we conducted 14 interviews where the respondents differed by gender, age, ethnicity and country of birth, employment and marital status (see Table 2). ${ }^{5}$ They were educated to Bachelor level or above, with many having Masters level qualifications, had stayed in the UK for different periods, and had different mother tongues (Bengali, Cantonese, English, German, Gujarati, Hindi, Turkish, Urdu). The interviews predominantly lasted for between 60-90 minutes; four had shorter durations and there was an outlier which lasted 146 minutes. Interviews were transcribed and the transcripts were circulated among the researchers for identification of key issues, interpretation and reflection. 
Table 2. Characteristics of semi-structured interview respondents

\begin{tabular}{|c|c|c|c|c|}
\hline Sex & Age & $\begin{array}{l}\text { Ethnic group } \\
\text { (self-ascribed) }\end{array}$ & Employment status & Marital status \\
\hline Male & $21-30$ & Asian (born in Pakistan) & Student & Married, no children \\
\hline Female & $31-40$ & $\begin{array}{l}\text { White other (born in } \\
\text { Germany) }\end{array}$ & Employed, Researcher & Married, no children \\
\hline Female & $31-40$ & Turkish/Dutch & $\begin{array}{l}\text { Employed, University } \\
\text { lecturer }\end{array}$ & Married, no children \\
\hline Female & $21-30$ & $\begin{array}{l}\text { Indian / Asian (born in } \\
\text { India) }\end{array}$ & Employed, Lawyer & Married, no children \\
\hline Female & $31-40$ & Chinese (born in Malaysia) & $\begin{array}{l}\text { Employed, software } \\
\text { developer }\end{array}$ & Divorced, one child \\
\hline Female & $21-30$ & $\begin{array}{l}\text { Black Caribbean (born in } \\
\text { UK) }\end{array}$ & $\begin{array}{l}\text { Employed, women's rights } \\
\text { charity }\end{array}$ & Married, no children \\
\hline Female & $51-60$ & $\begin{array}{l}\text { Anglo American (born in } \\
\text { US) }\end{array}$ & Employed, researcher & Divorced, one child \\
\hline Male & $21-30$ & Pakistani (born in Pakistan) & $\begin{array}{l}\text { Employed, software } \\
\text { developer }\end{array}$ & Married, no children \\
\hline Male & $41-50$ & Black British (born in UK) & Employed & Single, no children \\
\hline Female & $31-40$ & Indian (born in India) & Architect & Married, one child \\
\hline Female & $31-40$ & Indian (born in India) & $\begin{array}{l}\text { Employed, financial } \\
\text { analyst }\end{array}$ & Married, two children \\
\hline Male & $31-40$ & $\begin{array}{l}\text { Bangladeshi (born in } \\
\text { Bangladesh) }\end{array}$ & $\begin{array}{l}\text { Employed (part-time), } \\
\text { waiter }\end{array}$ & Married, no children \\
\hline Female & $21-30$ & $\begin{array}{l}\text { South Asian / Canadian } \\
\text { (brought up in Canada) }\end{array}$ & $\begin{array}{l}\text { Employed, women's rights } \\
\text { campaigner }\end{array}$ & Single, no children \\
\hline
\end{tabular}

As noted, it had become clear to us that it did not make sense to ask people directly about their 'ethnic identity' or 'ethnic group'. Instead we wanted to capture the dimensions that had emerged as important, regardless of whether respondents considered them to be part of 'ethnicity' or not. We tested the following dimensions: language (brought up in), national language of communication (English), religion (practised or brought up in), national identity, Britishness / Britain / being a Briton, country of birth, region currently living in, region brought up in, country of birth of parents/grandparents, nationality/citizenship, skin colour / appearance, identification as 'Black', and land of ancestors. While there were existing questions about the 'content' of most of these dimensions in the first wave of Understanding Society (i.e. which country 
they were born in, what their religion was, and so on), we had to develop ways of asking about language, ancestral land, region, skin colour and whether they self-perceived as 'Black'. For region and skin colour, we did not propose to collect the 'content' to which their replies related; but for language it was important to have some knowledge of which language people were referring to in order to analyse this dimension of their ethnicity. We therefore had also to develop a question defining their 'language brought up in'.

As well as these dimensions of ethnicity we wanted to explore various components of ethnicity that the earlier stages had demonstrated as being salient to ethnic identity and which also reflected the existing literature, namely: (i) personal identification / 'internal' importance to 'sense of who you are'; (ii) group belonging / connection / affinity; (iii) shared values; (iv) patterns of association; (v) pride. We derived the wording for the personal identification questions from those in the Citizenship Survey and already tested in the Innovation Panel (see Section 2).
We paid some attention to the problem of how best to capture group belonging, and how to distinguish it from personal identification, thus separating the private and social elements of identity. The interviews were, moreover, designed to test whether that distinction worked in practice for our respondents.

Box 1 gives the actual questions tested and explored during these interviews. These questions were preceded by some questions about their socio-demographic characteristics and each set of questions was followed by probes. ${ }^{6}$ The first question (QV2_1) was designed to measure personal identification. In one variant, interviewees were asked about personal identification as the first question and "sense of belonging" as a follow-up probe. In others, we reversed this approach. The follow-up questions were designed to measure degree of interaction (meeting and communicating) with members of 'own group' (QV2_2A) as identified by their responses to the first question, the extent of commonly shared values and beliefs with own group (QV2_2B), and pride in that group (QV2_2C). 


\section{Box 1. Excerpt from the semi-structured interview schedules}

QV2_1. I will now read out a set of questions. Please answer yes or no to each of them.

(1) Is the language that you spoke at home as a child important to your sense of who you are?

(1_add) And can I just check: what language was that

(2) If (1) is not English:

Is English important to your sense of who you are?

(3_filter) And can I ask, do you have or were you brought up in a religion? Yes/No

If yes, and what is that?

(3) Is your religion important to your sense of who you are?

Most people who live in the UK might see themselves as British in some way:

(4) Is being British important to your sense of who you are?

(5) Is the city/region where you live now important to your sense of who you are?

(6_filter) Where were you born?

(6) If outside UK: Is the country where you were born important to your sense of who you are?

(7_filter) And what region were you brought up in?

(7) If different from 5: Is the region in the country where you were brought up important to your sense of who you are?

(8_filter) Where was your father born?

(8) If different from the country where $R$ was born: Is the country where your father was born important to your sense of who you are?

(9_filter) Where was your mother born?

(9) If different from the country where R or R's father were born: Is the country where your mother was born important to your sense of who you are?

(10_filter) Is the land of your ancestors different from where you or your parents were born? If yes: And what would you say is the land of your ancestors?

(10) If Yes: Is (land of your ancestors) important to your sense of who you are? 
(Box 1 cont'd) $^{\prime}$

(11) Is your skin colour or other visible characteristics important to your sense of who you are?

(12_filter) And would you (ever) call yourself Black?

(12) If yes: Is being Black important to your sense of who you are?

For each $X$ that $R$ answered with YES or MAYBE/PARTLY/SOMEWHAT in QV1_1 or QV2_1

QV2_2. You mentioned that $X$ is important to your sense of who you are or that you feel a sense of belonging to $X$. Thinking about that please answer the following questions:

(A) Do you interact a lot with those who come from/are/speak/have the same _X_?

(e.g., language/religion/country of birth...)

1. Yes, a lot

2. Yes, a little

3. No

Question A changed in revised interview schedule

$\left(A^{\prime}\right) D$ you feel happy when you meet someone who speaks the same $X /$ has the same $X /$ comes from the same $X$ etc as you?

1. Yes

2. No

(B) Do you share many values and beliefs with those who come from/are/speak/have the same _X_? (e.g., language/religion/country of birth...)

1. Yes, a lot

2. Yes, a few

3. No

(C) Do you feel proud to be_X_? (e.g., language/religion/country of birth...)

1. Yes

2. No

3. Yes and No

4. Indifferent/don't care 
Early interviews showed that sense of self and belonging did seem to capture different ways of thinking about ethnic identity, and that there was variation across respondents in the relative weight accorded them. When the responses were probed, difference was expressed in terms of importance to sense of self being about 'identity', 'personal', 'what 'shapes $m e^{\prime}$. By contrast 'belonging' was felt to be about groupness, relationships, 'being subservient to a bigger entity', things 'bigger than self, 'comfort', ease and 'warmth'. As one respondent said: 'So they are two different things. So the first question is asking whether India is within me and the second question is- whether I am thinking am I part of India.' Another respondent reflected a shift in the relationship between the two over time when he said 'I feel I belong less to Kashmir but Kashmir is more in me.'

For some respondents the phrasing of belonging to a sometimes rather large grouping (Indian, Muslims) made the question awkward to answer in the form we had posed it. From the language of respondents, usually spontaneous, about feelings of warmth, or the pleasure they felt when they made contact with someone similar to them in some way ("if you saw another black person you were grinning your face off, in fact that's how I met my best friend"'), we developed a further variant which asked about how happy people felt when they met someone who shared the dimension with them (see question QV2_2A in Box 1). ${ }^{7}$ This was very successful in the later interviews, in that it appeared to strike a chord, and in two cases elicited a spontaneous illustrative anecdote.

Pride was associated with achievement for some and thus was not felt to be relevant to their ethnicity; for others it expressed a satisfaction or ease with who they were. Given that it was not salient in all cases and also the observation from a number of respondents that they didn't want to imply 'shame' by not expressing pride, a 'neither / nor' category seemed important to adequately capture this qualitative experience of pride. Interestingly, even among those who claimed that pride was concerned with achievement and so it was impossible to be proud of things that were just 'givens', there were still occasions when expressions of pride in such givens seemed very vital. One respondent explained this in terms of 'process' and psychological development, consistent with psychological theory: "If you were to say am I proud of being a black Caribbean woman then I would say 'yes' because there's been a process there, I've had to get to that point when I feel proud." We also found that pride did reveal a different pattern of response compared to 'importance to sense of self'. This became clearer when one respondent talked about how her identity changed with age and now she accepts certain things as part of her identity even if she is not proud of or agrees with those aspects.

When questioned about the extent of 'interaction' with those who were like the respondents in some dimension, several respondents found the question too broad or the response categories insufficiently specific. There was confusion about what type and frequency of interaction this question referred to - talking over the phone, meeting people every day, and so on. Some thought it needed to be comparative (more interaction with one group than another), or to work on a scale where they could specify a level "such as 6.5." Others found this question not very relevant, especially with respect to current region of residence: "Yeah, a kind of silly question. It may make sense for religion etc. but this question should not apply to a place you are at that moment, right."

The question on shared values and beliefs also failed to achieve acceptability. Often the groupings were, respondents thought, too large to have a cohesive set of core values and ideals. They found it difficult to pin-point what those core values and beliefs were for each group. This was less problematic in relation to religion but even here, some respondents found that the group was too diverse to make sense as having a common set of values: "It depends, even though they're [religion] we talk about the same stuff but we understand differently and sometimes we share some of the stuff but not all the stuff."

Following discussion and reflection on these two sets of questions we determined that these areas were better captured directly by questions on own values and on actual patterns of association and good information on social networks. ${ }^{8}$ It would then become an empirical question for researchers to ascertain the extent to which people did share values or associates within their 'group', however defined.

One of the key purposes of asking these questions in a longitudinal survey like Understanding Society is to measure change. So, we 
probed our respondents as to whether they would have answered differently at another time or in a different context. Some respondents said that they would have answered differently had they been asked at a different age, in different country or even at a different marital status: 'I think it changed because I think later on when I married someone outside my community and then I really found what it was like'.

To summarise, we concluded that:

- Personal identification and belonging are distinct and both relevant aspects of identity

- Expression of 'importance to sense of self' appeared to work for personal identification; as did 'happy to meet someone who...' for belonging

- Language of upbringing was meaningful to respondents as linking to formative experiences

- Similarly religion of upbringing, for those who didn't see themselves as currently religious still had the potential to be seen as part of identity and 'shaping self'

- Religion, region currently living in, region of upbringing, country of birth, and parental country of birth all made sense to respondents as potential components of identity, while actual affinity with any one of them varied substantially across individual respondents

- Colour was important, even if it was selfevident to most respondents. And there was no indication that they experienced discomfort in answering about it

- Pride produced varied responses - suggesting it can differentiate forms of identification. For some it made obvious sense, for others it was not appropriate as a way of thinking about their ethnicity

- Graduations (or more options) in response categories, including, for example a 'yes and no' middle response, were felt potentially important for pride, belonging, and importance to sense of self questions.

- The connection between food and culture / identity was spontaneously made by the majority of the respondents once again.

On the other hand,

- Black was rarely used in a political sense, and was predominantly understood as reflecting African or Caribbean heritage
- Britishness was overwhelmingly associated with civil status rather than culture or values

- It became clear that it is not appropriate to measure social interaction through subjective appraisal: it is not possible to get a single question that provides a meaningful measure. Instead, interaction should be measured directly, through questions on social networks and their composition

- It is an empirical question, not an attitudinal one whether values and beliefs are shared across 'groups', however they are constructed

\section{Proposed ethnic identity questions, cognitive testing and final recommendations}

The aim of the next stage was to put together a refined suite of questions, framed as 'final' and apparently suitable for fielding in a general survey context, to explore how these performed across a heterogeneous sample (see Appendix).

Our research so far led us to include questions on personal identification, belonging and pride with a gradation of responses. The recurrent spontaneous mention of food as a vehicle of transmission of ethnic identity and the interest in dress as one other potential aspect of ethnicity among researchers with whom we consulted on the prototypes, led us to develop specific questions on these topics. ${ }^{9}$ We also concluded that as part of the context for the more specific ethnic identity questions, a limited set of general identity questions, i.e., questions about the domains of identity such as gender identity, occupational identity, should also be asked.

We, along with four other researchers, ${ }^{10}$ cognitively tested a subset of these questions for comprehension and comfort level (using follow-up probes) on a sample of 22 persons of different ethnicity, age and generation (see Table 3). ${ }^{11}$ Respondents also varied by their mother tongue as measured by the main language spoken at home during childhood: Arabic, English, Oriya, Punjabi, Spanish, Swahili, Shanghaiese (dialect of Mandarin) and Urdu and by occupation and educational level. Interviews were recorded, and the interviewers wrote up notes on the responses, which were then discussed. 
Table 3. Characteristics of cognitive interview respondents

\begin{tabular}{|c|c|c|c|}
\hline Gender & Age group & Born in UK & Ethnic group (self-ascribed) \\
\hline Female & $16-20$ yrs & Yes & Indian \\
\hline Male & $20-29$ yrs & No & Indian \\
\hline Male & $20-29$ yrs & No & Arabic Middle Eastern \\
\hline Male & $20-29$ yrs & No & Pakistani \\
\hline Male & $20-29$ yrs & Yes & Black Caribbean \\
\hline Female & $30-39$ yrs & No & Chinese \\
\hline Female & $30-39$ yrs & No & Pakistani \\
\hline Male & $30-39$ yrs & No & Non-white \\
\hline Male & $30-39$ yrs & No & African \\
\hline Male & $40-49$ yrs & No & Middle Eastern \\
\hline Male & $40-49$ yrs & No & Venezuelan \\
\hline Female & $50-59$ yrs & No & German and Latin American \\
\hline Male & $50-59$ yrs & No & Pakistani \\
\hline Male & $50-59$ yrs & No & Black Caribbean \\
\hline Male & $50-59$ yrs & No & Indian \\
\hline Female & $40-49$ yrs & No & Libyan \\
\hline Female & $20-29$ yrs & Yes & White \\
\hline Female & $30-39$ yrs & Yes & White \\
\hline Male & $30-39$ yrs & No & White \\
\hline Female & $40-49$ yrs & No & White \\
\hline Male & $40-49$ yrs & Yes & White \\
\hline Female & $50-59$ yrs & Yes & White \\
\hline
\end{tabular}

Table 4 lists the questions that were cognitively tested and those that were finally recommended for inclusion in the second wave of Understanding Society. 
Table 4. Summary of final set of questions that were cognitively tested and those that were recommended for inclusion in Understanding Society ${ }^{1}$

\begin{tabular}{lll}
\hline Questions cognitively tested & $\begin{array}{l}\text { Questions recommended for } \\
\text { Understanding Society }\end{array}$ & $\begin{array}{l}\text { Comments on / outcome } \\
\text { of cognitive testing }\end{array}$
\end{tabular}

Ethnic Identity Module (face-to-face)

\begin{tabular}{|c|c|c|}
\hline $\begin{array}{l}\text { How important is } \\
\text { your sense of who you are? } \\
\text { - the main language spoken at } \\
\text { home during your childhood } \\
\text { - the country where you were } \\
\text { born } \\
\text { - the region or city where you } \\
\text { grew up } \\
\text { - the colour of your skin } \\
\text { - land of your ancestors (this was } \\
\text { filtered on "Would you say that } \\
\text { the land of your ancestors is } \\
\text { different from where you or } \\
\text { your parents or your } \\
\text { grandparents were born?") }\end{array}$ & $\begin{array}{l}\text { How important is } \\
\text { your sense of who you are? } \\
\text { - the main language spoken at home } \\
\text { during your childhood } \\
\text { - English language } \\
\text { - your religion/religion brought up in } \\
\text { - the region or city where you live } \\
\text { - the country where you were born } \\
\text { - the region or city where you grew } \\
\text { - up } \\
\text { - the country where your mother } \\
\text { - the country where your father was } \\
\text { born } \\
\text { - the country where your mother's } \\
\text { mother was born } \\
\text { - the country where your mother's } \\
\text { father was born } \\
\text { - the country where your father's } \\
\text { mother was born } \\
\text { - the country where your father's } \\
\text { father was born } \\
\text { - the colour of your skin }\end{array}$ & $\begin{array}{l}\text { These questions } \\
\text { worked well except } \\
\text { for the dimension } \\
\text { "land of your } \\
\text { ancestors" }\end{array}$ \\
\hline $\begin{array}{l}\text { Do you feel proud of } \\
\text { - the main language spoken at } \\
\text { - home during your childhood } \\
\text { the region or city where you } \\
\text { - Bere brought up in } \\
\text { consider yourself to be Black?") } \\
\text { - White (filtered on "do you } \\
\text { consider yourself to be } \\
\text { White?") }\end{array}$ & $\begin{array}{l}\text { Do you feel proud of } \\
\text { - the main language spoken at home } \\
\text { during your childhood } \\
\text { - English language } \\
\text { - your religion/religion brought up in } \\
\text { - the region or city where you live } \\
\text { - the country where you were born } \\
\text { - the region or city where you grew } \\
\text { - up } \\
\text { - the country where your mother } \\
\text { - the country where your father was } \\
\text { born } \\
\text { - the country where your mother's } \\
\text { mother was born } \\
\text { - the country where your mother's } \\
\text { father was born } \\
\text { the country where your father's } \\
\text { mother was born }\end{array}$ & $\begin{array}{l}\text { Worked well except } \\
\text { for the dimension } \\
\text { "White" and "Black" }\end{array}$ \\
\hline
\end{tabular}




\begin{tabular}{|c|c|c|}
\hline & $\begin{array}{l}\text { - the country where your father's } \\
\text { father was born } \\
\text { - the colour of your skin }\end{array}$ & \\
\hline $\begin{array}{l}\text { Do you feel happy when you meet } \\
\text { someone who } \\
\text { - speaks the same language } \\
\text { spoken at home during your } \\
\text { childhood } \\
\text { - has the same religion as you/as } \\
\text { the religion you were brought } \\
\text { up in } \\
\text { - comes from the same region or } \\
\text { city as you }\end{array}$ & $\begin{array}{l}\text { Do you feel happy when you meet } \\
\text { someone who } \\
\text { - speaks the same language spoken } \\
\text { at home during your childhood } \\
\text { - English language } \\
\text { - your religion/religion brought up in } \\
\text { - comes from the same country as } \\
\text { - you } \\
\text { - comes from the region or city as } \\
\text { - you were brought up in } \\
\text { - comes from the same region or city } \\
\text { - comes from the same country as } \\
\text { - your mother } \\
\text { - your father } \\
\text { - comes from the same country as } \\
\text { - your mother's mother } \\
\text { - comes from the same country as } \\
\text { your mother's father } \\
\text { - your father's mother } \\
\text { - your father's father } \\
\text { has the same skin colour as you }\end{array}$ & Worked well \\
\hline $\begin{array}{l}\text { How often do you eat the food } \\
\text { that is typical of } \\
\text { - the country where you were } \\
\text { born } \\
\text { - the country where your mother } \\
\text { was born }\end{array}$ & $\begin{array}{l}\text { How often do you eat the food that is } \\
\text { typical of } \\
\text { - the country where you were born } \\
\text { - the country where your mother } \\
\text { was born } \\
\text { - the country where your father was } \\
\text { born } \\
\text { - the country where your mother's } \\
\text { mother was born } \\
\text { - the country where your mother's } \\
\text { father was born } \\
\text { - the country where your father's } \\
\text { - the country where your father's } \\
\text { father was born }\end{array}$ & Worked well \\
\hline $\begin{array}{l}\text { How often do you wear clothes } \\
\text { that are typical of } \\
\text { - the country where you were } \\
\text { born } \\
\text { - the country where your mother } \\
\text { was born }\end{array}$ & & Did not work well \\
\hline
\end{tabular}




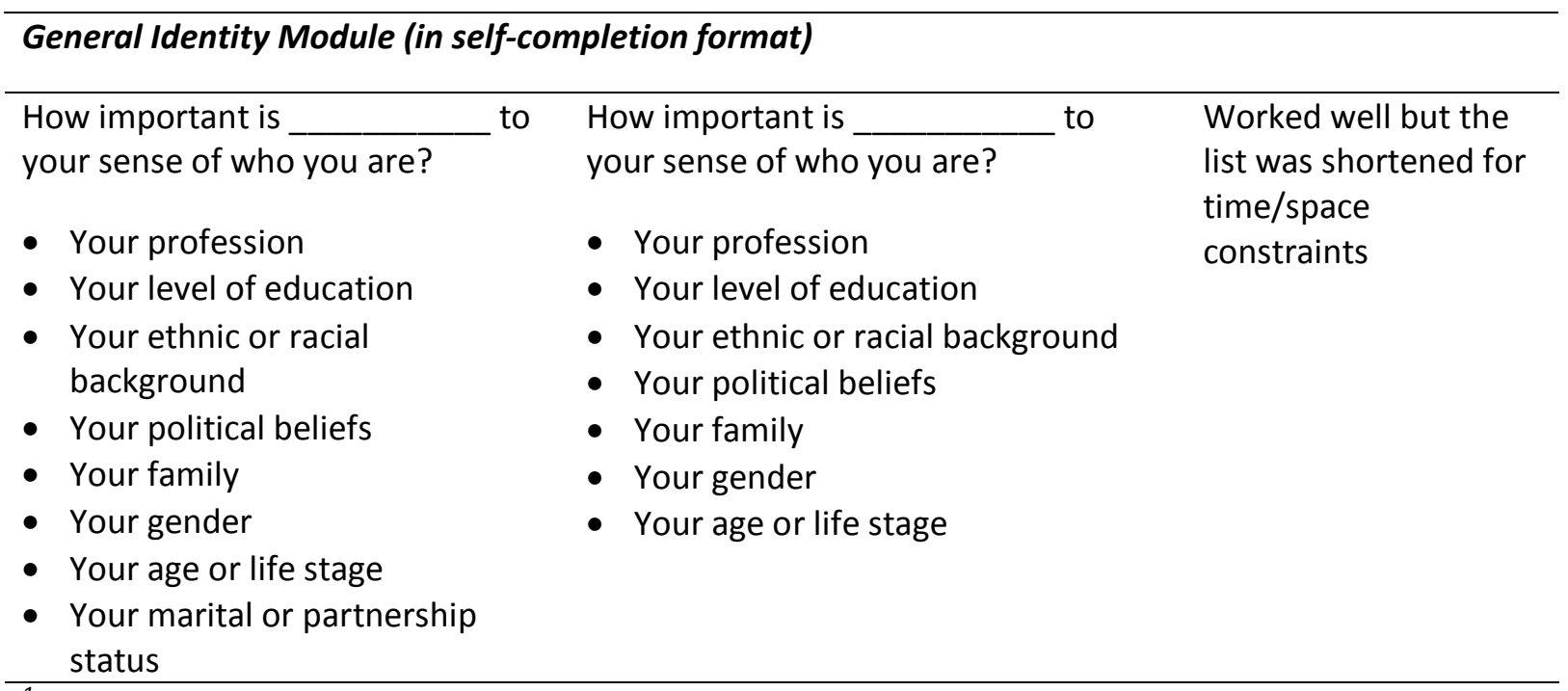

${ }^{1}$ All questions pertaining to parents' or grandparents' countries of birth are always filtered on that country being different from the preceding countries that were asked about. So, pride in mother's country of birth is asked only if mother's country of birth is different from own country of birth.

We found that respondents didn't have many difficulties with the questions, didn't seem to find them uncomfortable, and could distinguish between different components of identity. The experience of one or two interviews suggested that the proposed language question would benefit from a slight rewording to improve clarity and specificity. Across questions, respondents tended to prefer a range of responses rather than a simple yes/no and found that such a range, for example in relation to pride, enabled them to express an ambivalence that best reflected their position. For example, one respondent said: 'From my national background of course, white is the people we don't like. You know, white is domination, colonisation, supremism, all of these sort of bad things, although having said that, there is this aspiration to be white, which is horrible. So it sort of brings up all of these things and the problem I have with whiteness'. External consultation on the questions also elicited concerns that the responses offered for the 'Happy...' question were 'unbalanced' in the form tested. While most respondents were not uncomfortable answering it, the 'pride in being white' question did not seem very relevant to white respondents; and as 'Black' was synonymous with 'colour of skin' for respondents who regarded themselves as black, we finally decided to drop these questions.

The food question worked well but there was considerable confusion around the clothing question: some respondents interpreted it as meaning traditional clothing of the country they came from, even if rarely worn, others as the clothing worn every day (as intended). One respondent highlighted the specificity of religious as opposed to national clothing, recapitulating one of the focus group discussions and supporting our contention that questions on dress may be better suited to a suite of questions on religious practice: 'I thought about the traditional wear. I wear the scarf but I don't think that is part of traditional dress for my country. You can have a traditional outfit without the scarf in my country. The scarf is part of my religion.' Overall, the feedback indicated that we would struggle to get consistent understandings (and therefore interpretable responses) from a clothing question. The land of ancestors question also elicited some confusion: one respondent had not heard the term ancestor before, while others interpreted the question as asking about land owned by their ancestors.

The general identity module tested in selfcompletion format worked well, except for the domain of "family or marital status" which was not considered to be relevant by those who were single.

As a result of the testing, we retained the main questions on 'importance to sense of self' and 'happy to meet someone who' and pride, but introduced some modifications to the response categories. We also made slight modifications to the language question. We dropped the questions on dress and on 'land of ancestors'. The food questions were 
retained with some slight modification to the response categories. See Table 4 for the questions that were retained for inclusion in the survey. These questions have been fielded in Wave 2 of Understanding Society and the Wave 2 questionnaire can be found at: www.understandingsociety.org.uk.

To allow longitudinal research with a sufficiently broad population (as highlighted in Section 2), we recommended that these questions

- be asked of the ethnic minority boost sample, ethnic minorities living in areas of low minority group concentration in the main sample, a comparison sample from the general population sample and recent migrants

- be repeated at regular intervals- more frequent intervals for younger respondents and recent migrants.

\section{Conclusions and recommendations}

The culmination of this research process, defining general survey measures with which to measure ethnic identity, was the development of a suite of questions that were implemented in Understanding Society. Empirical analysis of their effectiveness is not possible until the data become available. Nevertheless, as a result of this study, we arrived at some general conclusions about which measures work, which don't, and what measures constitute the best data resource for research in this area, which can be applied more generally to other multi-purpose surveys where there is a desire or intention to engage with identity measurement. Some of our key recommendations on good measures of ethnic identity are:

- Ethnic identity measures should try to capture the different dimensions and components of ethnic identity

- Lack of consensus among researchers and respondents suggest survey questions should not impose any particular definition of ethnic identity but provide measures that allow maximum flexibility to researchers
- Ethnic identity is just one domain of identity. Therefore, questions to measure other aspects of identity should be asked simultaneously in order to place ethnic identity within the context of a person's overall identity(ies)

- Measures of identification, closeness and belonging, pride in own ethnic groups, as well as identity expressed through food, appear to capture distinct aspects of ethnic identity and can be asked directly of respondents

- Patterns of association with members of a group and their degree of shared values and beliefs are not aspects of identity per se, but are empirical questions on the extent to which expressed identity is consequential (or conversely structured by association and values). Values and patterns of association are therefore best measured directly and independently of identity questions.

Using multiple methods and a cumulative approach that built on successive insights, we were successful in answering the six questions we set out in section 2 and consequently in measuring different domains of identity and dimensions and components of ethnic identity. However, we were not able to develop measures for others' perceptions of a persons' ethnic identity, which is a crucial factor for understanding ethnic identity. We had explored this issue in our semi-structured interviews but were not able to learn much about how to measure this from respondents directly. Such issues can be captured in part through measures of perceived discrimination and harassment (which can and have been collected in surveys including Understanding Society), and through measurement of others' attitudes. However, the interplay between ascribed and owned identities remains a complex area to measure in a general household-level survey, and proved beyond the scope of this study.

We hope that the research carried out here will advance research into social identities by providing a set of model questions for other studies to employ (or adapt) in large-scale, representative surveys, and for their further evaluation and development.

\section{Acknowledgements}

We are grateful to participants in our focus groups and interviews and to our collaborators in conducting the research, in particular Liz Spencer, Punita Chowbey, Noah Uhrig and Heidi Mirza. We are also grateful to the thoughtful comments of three referees, which have contributed to the revision of this article. The support by the Economic and Social Research Council through the MiSoC research centre (RES-518-28-0001) and Understanding Society: the UK Household Longitudinal Study (RES-586-47-0001) is kindly acknowledged. 


\section{References}

Abrams D. (1996) Social Identity, Self as Structure and Self as Process. In WP Robinson. ed. Social Categories and Identities: Developing the Legacy of Henri Tajfel. Pp 143-168. Butterworth-Heinemann, Oxford.

Ahmad WIU and Evergeti V. (2010) The making and representation of Muslim identity in Britain: conversations with British Muslim 'elites'. Ethnic and Racial Studies, 33, 1697-1717.

Aspinall P. (2000) The challenges of measuring the ethno-cultural diversity of Britain in the new millennium. Policy and Politics, 28, 109-18.

Aspinall P. (2002) Collective terminology to describe the minority ethnic population: The persistence of confusion and ambiguity in usage. Sociology, 36, 803-16.

Banton M. (2000) Ethnic conflict. Sociology, 34, 481-498.

Barth F. (1969) Ethnic groups and boundaries. The social organization of culture difference. Universitetsforlaget, Oslo.

Battu $\mathrm{H}$ and Zenou Y. (2010) Oppositional identities and employment for ethnic minorities: evidence from England. The Economic Journal, 120, F52-F71.

Birt J. (2009) Islamophobia in the construction of British Muslim identity politics. In R Gale and P Hopkins. eds. Muslims in Britain: race, place and identities. Pp 210-227. Edinburgh University Press, Edinburgh.

Bloor M, Frankland J, Thomas M and Robson K. (2001) Focus Groups in Social Research. London, Sage.

Brubaker R and Laitin D. (1998) Ethnic and nationalist violence. Annual Review of Sociology 24, 423-452.

Burton J, Nandi A and Platt L. (2010) Measuring ethnicity: challenges and opportunities for survey research. Ethnic \& Racial Studies 33, 1332-1349.

Collins D. (2003) Pretesting survey instruments: an overview of cognitive methods. Quality of Life Research, $12,229-238$.

Constant AF and Zimmermann KF. (2008) Measuring Ethnic Identity and its Impact on Economic Behavior. Journal of the European Economic Association, 6, 424-433.

De Leeuw ED. (2005) To mix or not to mix data collection modes in surveys. Journal of Official Statistics, 21, 233-255.

Erikson EH. (1963) Childhood and Society. 2nd edition. Norton, New York.

Finney N and Simpson L. (2009) Sleepwalking to Segregation? Challenging Myths About Race and Migration. The Policy Press, Bristol.

Fossey E, Harvey C, McDermott F and Davidson L. (2002) Understanding and evaluating qualitative researcher. Australian and New Zealand Journal of Psychiatry, 36, 711-32.

Georgiadis A and Manning A. (2011) Change and continuity among minority communities in Britain. Journal of Population Economics, 24, 541-568.

Güveli A and Platt L. (2011) Understanding the religious behaviour of Muslims in the Netherlands and the UK. Sociology. 45, 1008-27.

Heath A and Cheung SY. (2006) Ethnic penalties in the labour market: Employers and discrimination. Department for Work and Pensions Research Report No. 341. Corporate Document Services, Leeds.

Jenkins R. (1994) Rethinking ethnicity: identity, categorization and power. Ethnic and Racial Studies, 17, 197223.

Manning A and Roy S. (2010) Culture Clash or Culture Club? National Identity in Britain. The Economic Journal, 120, F72-F100.

Morse JM, Barrett M, Mayan M, Olson K and Spiers J. (2002) Verification strategies for establishing reliability and validity in qualitative research. International Journal of Qualitative Methods, 1, 1-19.

Nandi A and Platt L. (2011) Effect of interview modes on measurement of identity. Understanding Society Working Paper 2011-02.

Olzak S. (2006) The Global Dynamics of Racial and Ethnic Mobilization. Stanford University Press, Stanford.

Phinney JS. (1990) Ethnic Identity in Adolescents and Adults: Review of Research. Psychological Bulletin, 108, 499-514.

Phinney JS. (1992) The Multi-group Ethnic Identity Measure: A new scale for use with diverse groups. Journal of Adolescent Research, 7, 156-176.

Presser S, Couper M, Lessler JT, Martin E, Martin J, Rothgeb JM and Singer E. (2004) Methods for Testing and Evaluating Survey Questions. Public Opinion Quarterly, 68, 109-130.

Schaafsma J, Nezlek JB, Krejtz I and Safron M. (2010) Ethnocultural identification and naturally occurring interethnic social interactions: Muslim minorities in Europe. European Journal of Social Psychology, 40, 1010-28.

Tajfel H. (1981) Human groups and social categories. Cambridge University Press, Cambridge.

Turner JC, Oakes PJ, Haslam SA and McGarty C. (1994) Self and Collective: Cognition and Social Context. Personality and Social Psychology Bulletin, 20, 454-463. 


\section{Appendix}

\section{Identity module in the Citizenship Survey 2007-8}

\section{SHOWCARD}

We'd like to know how important various things are to your sense of who you are. Please think about each thing I mention, and tell me how important it is to your sense of who you are? Please choose your answer from the card.

Your occupation?

$\begin{array}{ll}1 & \text { Very important } \\ 2 & \text { Quite important } \\ 3 & \text { Not very important } \\ 4 & \text { Not at all important } \\ & \text { DON'T KNOW }\end{array}$

Your ethnic or racial background?

1 Very important

2 Quite important

$3 \quad$ Not very important

$4 \quad$ Not at all important

DON'T KNOW

The question was then repeated for the other domains of identity: your religion, national identity, where you live, your interests, your family, your social class (working, middle), the country your family came from originally, your gender, your age and life stage, your level of income and your level of education (in that order).

\section{Identity module fielded in $2^{\text {nd }}$ wave of the Innovation Panel:}

We'd like to know how important various things are to your sense of who you are. Please think about each thing I mention, and tell me whether you think it is important, not very important or not important to your sense of who you are?

READ OUT EACH AND CODE

1 Important

$2 \quad$ Not very important

$3 \quad$ Not at all important

(a) Your occupation? INTERVIEWER: IF DK PROBE: Is that because you are retired?

And then repeated across the other domains, which were: ethnic or racial background, religion, national identity, political beliefs, family, father's ethnic group, mother's ethnic group (if different from father's), marital or partnership status, gender, age and life stage, level of education, sexual orientation. One half of the sample received 'occupation' for the first domain, the other half received the version with 'profession'.

Follow-up:

Your ethnic background was [answer at ethnic or racial background] to your sense of self. When you think about your ethnic background, do you think of your...READ OUT

\section{CODE ALL THAT APPLY}

1 Religion

2 National identity

3 Your father's or mother's ethnic group

96 None of these 


\section{Endnotes}

${ }^{1}$ Throughout this paper we will refer to personal affiliation to an ethnic group, participation in activities related to that group including food habits, feelings of belonging to the group, attitude towards the group etc. as components of identity and country or region of origin/birth, religion, ethnic or racial background, country of residence, ancestral region or country etc. as dimensions of ethnic identity.

${ }^{2}$ In this paper we will refer to these aspects of a person's overall identity, such as gender, occupation, age or life stage etc. as domains of identity.

${ }^{3}$ The Citizenship Survey was a large-scale, cross-sectional government survey that ran from 20012011. It was carried out every two years from 2001 but in 2007 moved to a continuous design. It covered issues of community, social cohesion, race equality, volunteering and active citizenship. As well as a 10,000 person population sample from England and Wales it incorporated a 5,000 person ethnic minority boost sample.

${ }^{4}$ Liz Spencer designed the focus group schedule and facilitated four of the focus groups. Punita Chowbey conducted 2 focus groups jointly with the authors. The authors facilitated the remaining focus group.

${ }^{5}$ Interviews were carried out by the two authors and by Punita Chowbey (two interviews) and Heidi Mirza (two interviews).

${ }^{6}$ Entire interview schedules including probes are available from the authors upon request.

${ }^{7}$ As questions on social interaction and shared values and beliefs were not working very well, we dropped these in this variant. We discuss this further below.

${ }^{8}$ These social network questions have since been implemented in the third wave of Understanding Society. See the Social Networks module in the adult interview questionnaire (p.98 in http://research.understandingsociety.org.uk/files/design/materials/questionnaires/wave3/Underst anding Society Mainstage Wave 3 Questionnaire v01.pdf)

${ }^{9}$ The Ethnicity Strand Advisory Committee for the survey, with whom we had consulted, had suggested asking about clothing typical of one's ethnic background to capture another aspect of lived identity.

${ }^{10}$ Sarah Budd, Emily Kean, Allison Patterson, Noah Uhrig.

${ }^{11}$ Entire cognitive interview schedule is available from the authors upon request. 